\title{
Da Resignação À Mundanidade: mudança de paradigma no Evangelicalismo Pentecostal e o confronto entre a Teologia da Prosperidade e a Teologia da Graça em John Wesley
}

\author{
Orientador: Joel Portella Amado \\ Doutorando: Josimir Albino do Nascimento \\ Área de Concentração: Teologia Sistemático-Pastoral \\ Linha de Pesquisa: Religião e Modernidade \\ Projeto de Pesquisa: Antropologia Teológica em contexto de pós-moderni- \\ dade
}

Uma parcela significativa do evangelicalismo brasileiro, o neopentecostalismo, herdado da América do Norte, adere à Teologia da Prosperidade, cujos pressupostos vão de encontro ao núcleo da identidade cristã, a Teologia da Graça. Esta tese propõe analisar os fatores econômicos, políticos, sociais e religiosos que contribuíram para a mudança de paradigma, fazendo com que uma vertente do evangelicalismo pentecostal migrasse da religiosidade pautada na resignação para uma forma de manifestação religiosa norteada pela economia de mercado, o capital e o lucro, distanciando-o da sua origem de santidade e da Teologia da Graça, conforme ensinadas pelo pai do movimento de santidade, John Wesley e o aproximando do secularismo. Como instrumento de verificação para alcançar o resultado esperado, os elementos norteadores desta pesquisa estão alicerçados na Teologia Sistemática e na corroboração da história, da sociologia e da antropologia.

Palavras-chave: Teologia da Prosperidade. Teologia da Graça. Neopentecostalismo. 